\title{
Nanotechnology Techniques
}

National Cancer Institute

\section{Source}

National Cancer Institute. Nanotechnology Techniques. NCI Thesaurus. Code C62318.

Systematic procedures which are utilized for the manipulation of materials at the nanoscale (i.e., less than 100 nanometers). 